\title{
Vitis Labrusca L. grapes cultivars under hydric stress in protected cultivation
}

\author{
Gentil Luiz Miguel Filho', Douglas José Marques², Paulo Sergio de Souza ${ }^{3}$, \\ Lucas Eduardo de Oliveira Aparecido ${ }^{4}$, Luciano Dias Cabral Neto ${ }^{5}$
}

\begin{abstract}
The expansion of the Brazilian wine border, combined with the development of new cultivars adapted to different regions, highlight the need for more information on irrigation handling for new cultivars in protected cultivation. Therefore, this study aimed to evaluate grapevine cultivars submitted to different percentages of water replacement in the soil in conditions of the Southern region of Minas Gerais with the use of irrigation. The experiment was installed and developed from 2014 to 2016. The experimental design used was random blocks, with five replicates and the treatments were disposed in subdivided plots, with three replacement percentages (30, 50 and 100 $\%$ of necessary water replacement for this type of soil) and in the subplots four grapevine cultivars belonging to Vitis labrusca L species. ('Isabel', 'Isabel Precoce', 'BRS-Cora' and 'BRS-Violeta'). The research concluded that these cultivars increased $75 \%$ the bunch length, $71 \%$ of the bunch weight, $39 \%$ the production of bunch of grapes, $52 \%$ the $\mathrm{pH}, 84 \%$ the soluble solid content and $60 \%$ the reduction of total acidity content, $60 \%$ to $100 \%$ of water replacement. 'Isabel precoce' cultivar in water deficit conditions obtained the best productive results.
\end{abstract}

Index terms: Vitis labrusca L., table grape, irrigation.

\section{Produção de cultivares de uvas Vitis Labrusca $\mathbf{L}$. sob estresse hídrico em cultivo protegido}

Corresponding author: gentil.miguel@muz.ifsuldeminas. edu.br

Received: January 30, 2020 Accepted: May 11, 2020

Copyright: All the contents of this journal, except where otherwise noted, is licensed under a Creative Commons Attribution License.

\section{$(\mathrm{cc}) \overline{\mathrm{EY}}$}

Resumo - A ampliação da fronteira vitícola brasileira, aliada ao desenvolvimento de novas cultivares adaptadas às diferentes regiões evidenciam a necessidade de maiores informações sobre o manejo da irrigação para novas cultivares, em cultivo protegido. Sendo assim, este trabalho teve como objetivo avaliar cultivares de videira submetidas a diferentes porcentagens de reposição de água no solo, nas condições da região sul de Minas Gerais com o uso de irrigação. O experimento foi implantado e desenvolvido nos anos de 2014 a 2016. O delineamento experimental foi em blocos ao acaso, com cinco repetições. Os tratamentos foram dispostos em parcelas subdivididas, com três porcentagens de reposição (30; 50 e 100 \% de reposição necessária de água para esse tipo de solo) e, nas subparcelas, as quatro cultivares de videira pertencentes à espécie Vitis labrusca L. ('Isabel', 'Isabel Precoce', 'BRS-Cora' e 'BRS-Violeta'). Conclui-se com a pesquisa que as cultivares aumentaram em $75 \%$ o comprimento do cacho, $71 \%$ a massa dos cachos, $39 \%$ a produção de cachos de uva, $52 \%$ o pH, $84 \%$ o teor de sólidos solúveis e $60 \%$ a redução do teor de acidez total com $100 \%$ da reposição de água. A cultivar Isabel precoce nas condições de déficit hídrico obteve os melhores resultados produtivos.

Termos para indexação: Vitis labrusca L., uva de mesa, irrigação.

\footnotetext{
${ }^{1}$ Agricultural Technician, MSc, IFSULDEMINAS, Muzambinho-MG, Brazil. E-mail: gentil.miguel@muz.ifsuldeminas.edu.br ${ }^{(0 R C I D 0}$ 000-00021102-1961)

${ }^{2}$ Agronomist, Professor, Universidade Federal de Uberlândia - Institute of Agricultural Sciences, Monte Carmelo-MG, Brazil. E-mail: douglasjmarques81@yahoo.com.br ${ }^{\text {(ORCID 0000-0002-0598-2141) }}$

${ }^{3}$ Agronomist, Professor, IFSULDEMINAS, Muzambinho-MG, Brazil. E-mail: paulo.souza@ muz.ifsuldeminas.edu.br (0RCID 0000-0001-6390-8671) ${ }^{4}$ Agronomist, Professor, Instituto Federal do Mato Grosso do Sul, Naviraí-MS, Brazil. E-mail: lucas.aparecido@ifms.edu.br (ORCID 0000-0002-4561-6760) ${ }^{5}$ Agronomist, MSc, Universidade Federal de Uberlândia- Institute of Agricultural Sciences, Uberlândia-MG, Brazil. E-mail: lucianodiasagro@ gmail.com ${ }^{\text {(ORCID } 0000-0002-7338-1129)}$
} 


\section{Introduction}

Among the grapes produced in Brazil, half is explored for processing (wines, juices etc.) and the other half is aimed at meeting consumption demands in natura. The viticulture for processing is strongly concentrated in the states of Rio Grande do Sul, Santa Catarina and Paraná, while the production of table grapes predominates the states of Pernambuco, Bahia, São Paulo and Minas Gerais. There was a highly expressive growth in table grapes exports (909.9\%) between 1998 and 2019, due to an average annual increase of the order of $7.6 \%$. The production and per capita consumption also increased significantly during this period, although at lower rates than exports, $122.0 \%$ and $68.1 \%$ respectively (MAIA, et al., 2020).

The adoption of the trellis training systems in $\mathrm{Y}$ form, associated or not to protected cultivation, emerged as an alternative for the reduction of manpower and the use of agrochemicals, combined with the increase in the product quality and, therefore, the profitability and reduction of diseases in the grapevine culture (HERNANDES; PEDRO JÚNIOR, 2015).

There are more than 5,000 grape varieties in the world, but the consumer is used to finding in the market and supermarkets, only two or three varieties. Despite this large availability of varieties, the wine growers, end up specializing in the production of only one or two cultivars. This wide diversity of species and cultivars can produce grapes with distinct physicochemical characteristics that need studies (AEB and al., 2007).

The Genetic Improving Program "Brazil Grapes" in 2003 launched the first Brazilian grape cultivars (CAMARGO et al., 2003). Genetic materials used in the Brazilian vineyards present high variability, and approximately 40 cultivars belonging to the Vitis labrusca species and approximately 120 cultivars belonging to the Vitis vinifera species (CAMARGO et al., 2011).

Although the Southern Brazil region is considered the largest grape producer in the country, it is worth pointing out that the grape produced in this region is intended, mainly for wine production, while in the Southeast and Northeast regions the production of table grapes predominates. The Southern of the state of Minas Gerais was always highlighted as a table grape production center, in particular the Andradas and Caldas region, but the farmers have few cultivars options for planting. In Caldas region, there are new fields that aimed at the production of grapes for table, fine wines and juice and for experimental purpose (AMORIM, et al., 2005).

There was a large increase in the grapevine researches with the expansion of the Brazilian viticulture border, mainly with additional support for rural entrepreneurship. New definitions of technologies and handling, certification of wine growing products, geographical indications, organic production have been emerging through these researches, in addition to technologies for the selection of clones and new cultivars adapted to different regions (NACHTIGAL et al., 2010).

The climate of the region is a key element in the determination of the characteristics of wines not only in global terms, but also in the climatic conditions of the Brazilian wine growing regions. The climate of the Southern Minas Gerais is characterized with average monthly air temperature of $20.6{ }^{\circ} \mathrm{C}$, rainfall of $255 \mathrm{~mm}$ and evapotranspiration of $71.4 \mathrm{~mm}$. The imposition of moderate water deficiency to grapevine in certain phenological stages has a positive impact on the concentration of sugars, acidity, $\mathrm{pH}$ and phenolic compounds in the must (LUCANO et al., 2013). These characteristics are responsible for various attributes such as color, aroma, body and structure.

It is known that irrigation can affect the production and the quality of table grape (SERMAN et al., 2004) and wine grape (SANTOS; KAYE, 2009). Water requirement for grape crop varies at different development stages and the water deficit can cause, during the initial phase and in the maturation phase of the berries, reduction in the size of the fruits and delay in the ripening of the bunches (ÁVILA NETO et al., 2000) and it is necessary to evaluate the adaptation of new cultivars submitted to water deficit.

Therefore, this study aimed to evaluate grapevine cultivars submitted to different percentages of water replacement in the soil in conditions of the Southern region of Minas Gerais.

\section{Material and Methods}

The experiment was installed and developed in the Federal Institute of Education, Science and Technology of Southern Minas Gerais - Campus Muzambinho (MG), Brazil, in the Fruticulture Sector in the harvest from 2014 to 2016 . The experimental area is delimited by the geographical coordinates: $21^{\circ} 20^{\prime} 59.94^{\prime} \mathrm{S}$ of latitude and $46^{\circ} 31^{\prime} 34.82^{\prime} \mathrm{W}$ of longitude, having as average altitude of 1013 meters (Figure 1). 
1. Slopes field

2. Mining center

3. Jequitinhonha

4. Metropolitan area of Belo Horizonte

5. Northwest of Minas Gerais

6. North of Minas Gerais

7. West of Minas Gerais

8. South/Southest of Minas Gerais

9. Mineiro Triangle Region

10. Mucuri Valley

11. Doce River Valley

12. Forest Zone

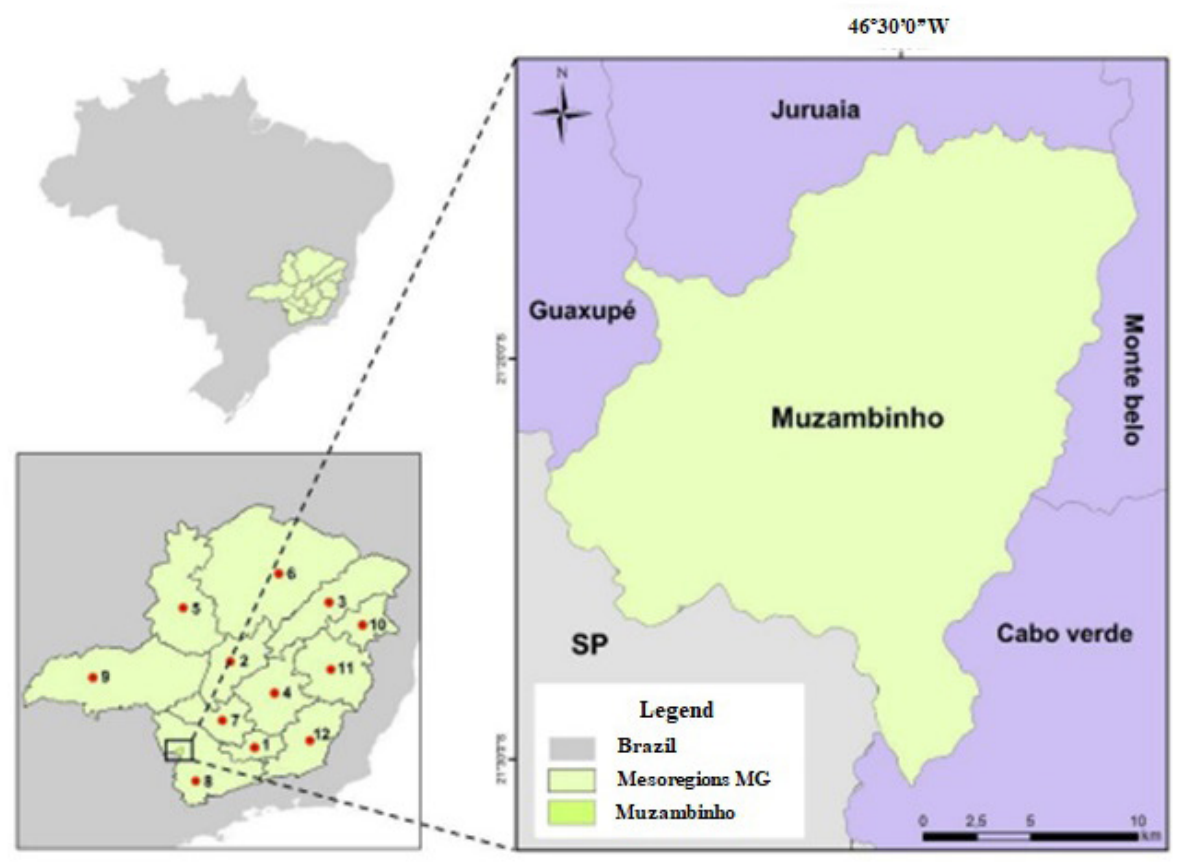

Figure 1. Location of Muzambinho municipality in the State of Minas Gerais, Brazil. Fonte: (APARECIDO and SOUZA, 2019).

The plant training system was in the form of trellis or ' $\mathrm{Y}$ ' form, with plastic coverage system, high tunnel model (Figure 2). The system is in Y form with tilted lateral arms, fixed in the support posts. Wires were used for the installation of the ' $\mathrm{Y}$ ' training system, one for supporting the spur cord, two from each side to tie the branches, two external wires were placed on each side for lateral lashing and another one on the top to support the material to be used in the cover of the vineyard and protection of the grapevines as recommended by Hernandes and Pedro Junior (2015). Diffusing agrofilm was used for covering $(150 \mu$ in thickness) and it is characterized by being photo selective, antivirus, light diffuser, anti-aesthetic and resistant to ultraviolet rays (MARQUES et al., 2019).

The area was cleaned for the experiment setup, using the desiccant herbicide followed by the elimination of crop remains. The soil $(0$ to $20 \mathrm{~cm})$ of the experimental area presented the following characteristics: $\mathrm{pH}$ of 6.41 (water-1:2.5); 3.28 dag $\mathrm{kg}$ of OM; $92.2 \mathrm{mg} \mathrm{dm}^{3}$ of P (Mehlich 1); $370 \mathrm{mg} \mathrm{dm}^{3}$ of K (Mehlich 1); $6.0 \mathrm{cmol}_{\mathrm{c}} \mathrm{dm}^{3}$ of $\mathrm{Ca}(\mathrm{KCl}$ extractor $1 \mathrm{~mol}$ L); $1.64 \mathrm{cmol}_{\mathrm{c}} \mathrm{dm}^{3}$ of $\mathrm{Mg}$ ( $\mathrm{KCl}$ extractor $\left.1 \mathrm{~mol} \mathrm{~L}\right) ; 0.0$ $\mathrm{cmol}_{\mathrm{c}} \mathrm{dm}^{3}$ of $\mathrm{Al}(\mathrm{KCl}$ extractor $1 \mathrm{~mol} \mathrm{~L}) ; 2.89 \mathrm{cmol}_{\text {c }}$ $\mathrm{dm}^{3}$ of $\mathrm{H}+\mathrm{Al}$ (SMP extractor).

The experiment implementation started with the marking and alignment of the furrow for the planting of the grapevine nursery trees with $360 \mathrm{~m}^{2}$ planting density in September 2010. Bare grapevine nursery trees were used, grafted on '1103 Paulsen' rootstock using the table graft method. The nursery trees were acquired in EPAMIG-Caldas. The rustic grapevine cultivars (Vitis labrusca L.) used were: Isabel, Isabel Precoce, BRSCora, BRS-Violeta. The grapevine planting took place in
2014, and the first pruning was held on July 30th, 2015 with the withdrawal of the aerial part above the wire $(1.10 \mathrm{~m})$ leading the sprouts to form the cultivars' rods. The cultivars began to enter into maturation by the end of November, and the evaluations were conducted on December $16^{\text {th }}, 2015$ to 2016 . The crop handlings were conducted as recommended for the crop (NACHTIGAL et al., 2010) with preventive spraying of copper base; control of diseases and pests; fertilization for plant formation and fruit production; control of invasive plants with the use of herbicides in the planting line; and the use of brush cutter between the furrow were conducted according to the recommendations for the region. The grapevine production cycle was divided into eight separate phenological stages, as follows: (a) the period of sprout; (b) vegetative development; (c) pre and full bloom; (d) first phase of the fruit growth; (e) fruit growth stop; (f) second phase of the fruit growth; g) final maturation of the fruit; and h) phenological rest. Figure 2 shows the grapevine plants in the different phenological stages, short pruning with one bud (Figure 2A), budding (Figure 2B), green grapes (Figure 2C) and grapes starting to color (Figure 2C) during the research from 2015 to 2016. 

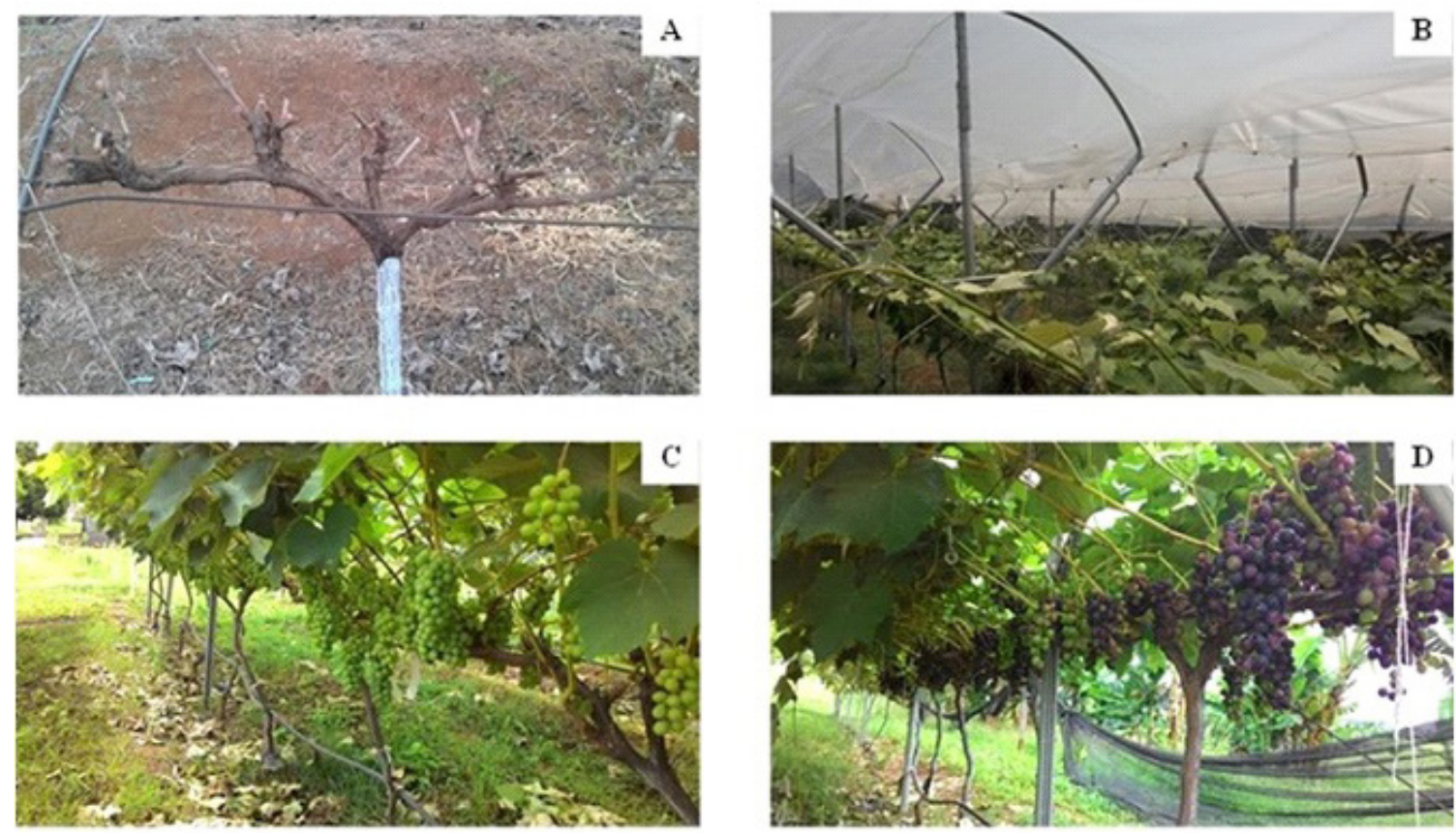

Figure 2. Short pruning with a bud (A), budding (B), green grapes (Figure C) and grapes beginning to color (C) in the experiment during the years 2014 to 2016 (average of three years).

The experimental design used was random blocks, with five replicates. The treatments were set in subdivided plots, with three replacement percentages (30,50 and 100 $\%$ necessary water replacement for this type of soil) and in the subplots the four grapevine cultivars belonging to Vitis labrusca L species. (Isabel, Isabel Precoce, BRS-Cora and BRS-Violeta species. Each subplot was composed of six plants, the spacing used was $2.50 \mathrm{~m}$ between lines and $1.00 \mathrm{~m}$ between plants, arranged in three lines, making an area of $25 \mathrm{~m}^{2}$ for each experimental subplot and 900 $\mathrm{m}^{2}$ the total area of the experiment. The plant training system was in the form of trellis or ' $Y$ ' form, with plastic coverage system, high tunnel model (Figure 2). The experiment was separated in three tracks (A, B and C), in track A was supplied a water layer of $30 \%$ necessary water replacement for this type of soil, in track B 50\% necessary water replacement for this type of soil and in track C 100 $\%$ necessary water replacement for this type of soil. The $100 \%$ water layer corresponds to the total replacement of the evapotranspiration that the crop presented during that period. The irrigation shift used among the irrigation was three days. Meteorological data were measured by the automatic station of IFSULDEMINAS, Campus Muzambinho, MG, Brazil. The irrigation handling was conducted applying the water balance method, using SYSWAB software (GASPAR et al., 2015). The predominant climate in the region is $\mathrm{B}_{4} \mathrm{rB}_{2}$ according to the climate classification of Thornthwaite (1948), and it is considered a wet climate with small water deficiency (APARECIDO et al., 2014). The reference evapotranspiration was estimated by FAO Penman-
Monteith method according to (ALLEN et al., 1998). The soil water availability in the field capacity was calculated based on humidity data (FIETZ, 1999). The sequential daily climatological water balance method was used for irrigation handling, conducted according to (THORNTHWAITE, 1948), during the research was quantified average temperature (Figure 3A), precipitation (Figure 3B), potential evapotranspiration ETP (Figure 4A), real evapotranspiration EPR (Figure 4B), water storage in the soil STO (Figure 4C), water deficiency DEF (Figure 5A) and water excess EXC (Figure 5B). 


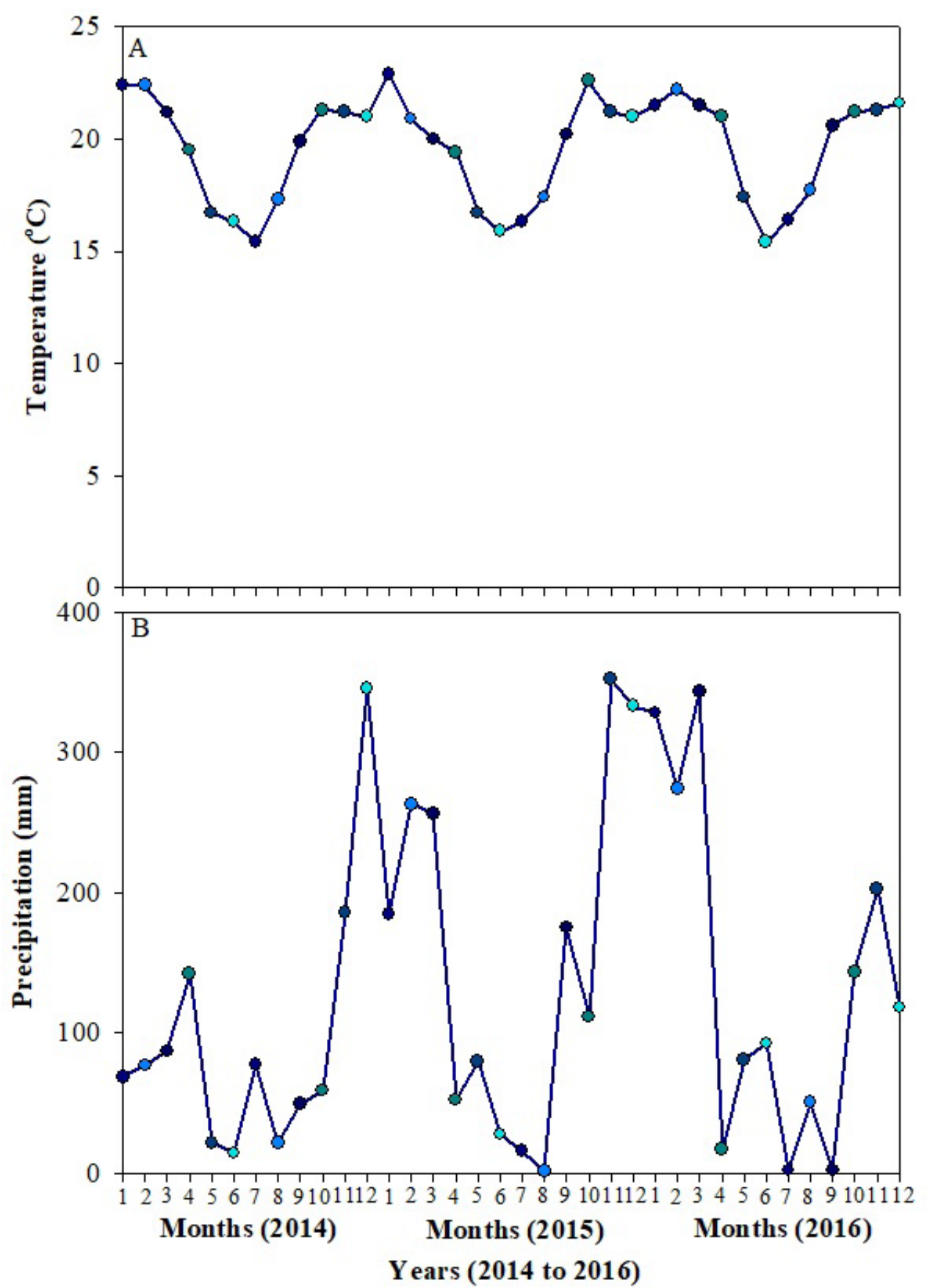

Figure 3. Temperature (A) and precipitation (B) carried out in the years 2014 to 2016 (average of three years). 


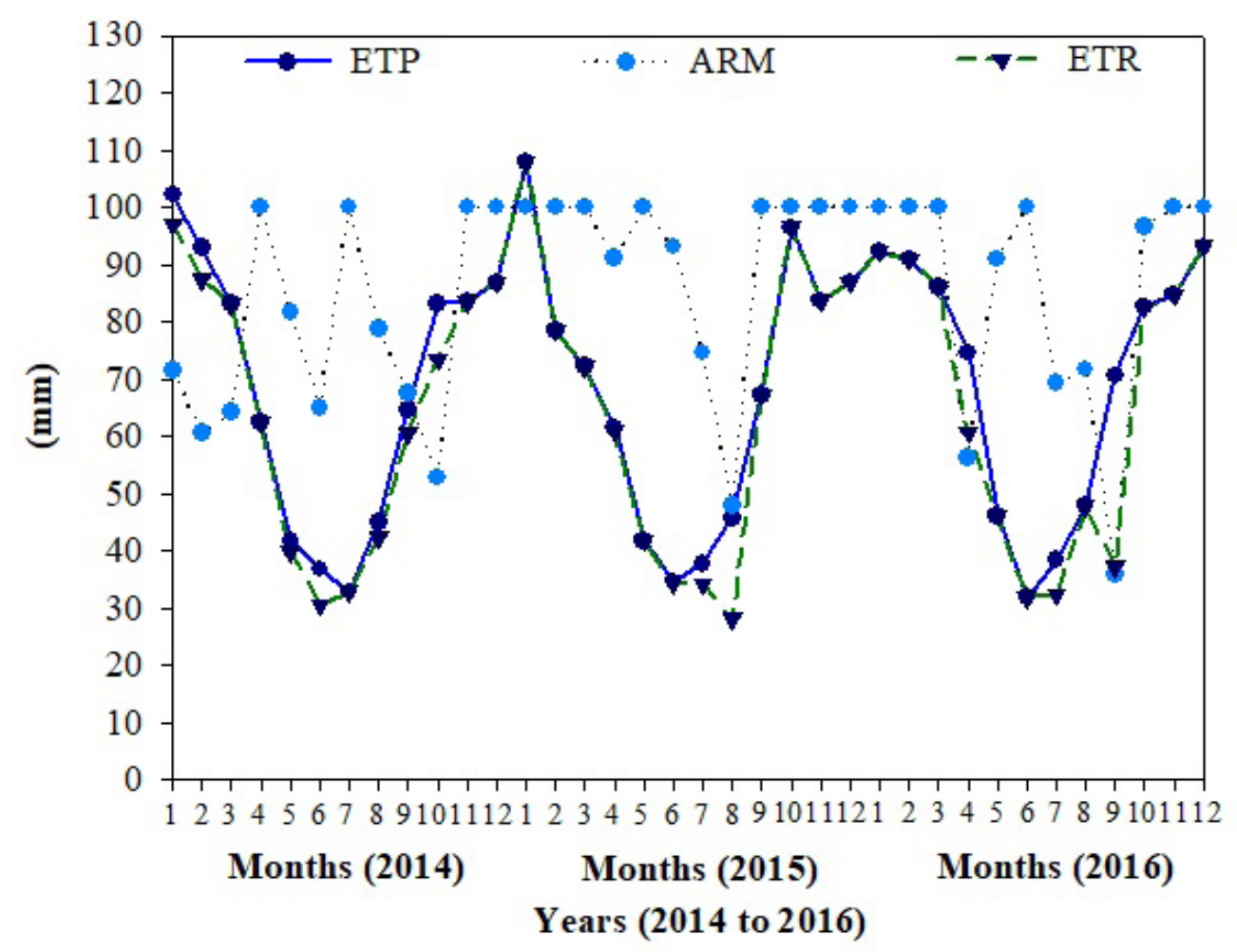

Figure 4. Potential evapotranspiration-ETP (A), real evapotranspiration-ETR (B), soil water storage-STO (C) carried out in the years 2014 to 2016 (average of three years).

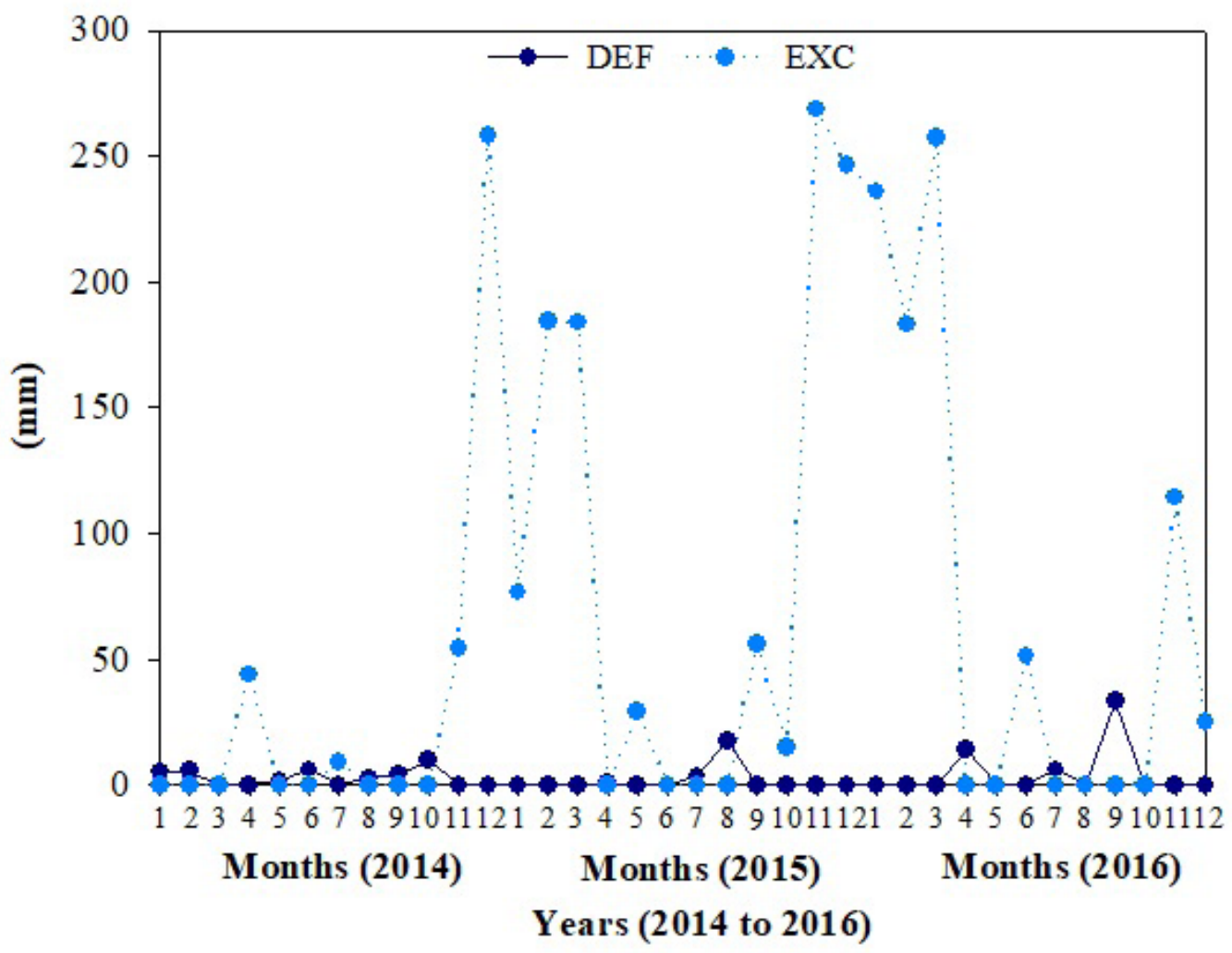

Figure 5. Water deficiency-DEF (A) and water excess-EXC (B) carried out in the years 2014 to 2016 (average of three years). 
The water and climate balance recorded during the experiment is presented in Figure 2, 3 and 4. The drip irrigation method used was with self-compensating and anti-draining drippers, with a flow rate of $2.5 \mathrm{~L} \mathrm{~h}^{-1}$. The assessment of the distribution uniformity coefficient was conducted obtaining $96 \%$ uniformity according to the methodology proposed by Keller and Karmeli (1975) which consists of squaring the irrigation subunit area, using the first lateral line, the lines located at $1 / 3$ and $2 / 3$ and the last one. The same procedure was adopted according to the number of emitters by lateral line or the number of plants by line within each irrigation subunit. The flow of each emitter was measured using aluminum containers with a liter of capacity, with the collection time per emitter of three minutes.

The harvest was conducted from 2015 to 2016 according to recommendations (Antoniolli \& Lima, 2008) and the following parameters were evaluated: bunch length $\left(\mathrm{cm} \mathrm{plant}^{-1}\right.$ year $\left.{ }^{-1}\right)$, bunch weight (grams plant $^{-1}$ year $\left.{ }^{-1}\right)$, grape production $\left(\mathrm{kg} \mathrm{year}^{-1}\right)$, the content of soluble solids ${ }^{\circ}$ Brix, acidity and $\mathrm{pH}$ according to $\mathrm{AOC}$ (2012) due to the cultivars and percentages of water replacement for this type of soil for harvests conducted in the years 2015 to 2016 (average of 2 years).

Manual harvest was conducted beginning at 8:00 a.m. and ending at 11:00 a.m. using pruning scissors, making the selection and trimming of the bunches, and the disposal of the berries that eventually presented some kind of defect. During the harvest bunches samples were taken, and the bunches were labelled. Each sample was packed in cardboard box, export type, single piece, with external dimensions of $470 \mathrm{~mm} \times 290 \mathrm{~mm} \times 120 \mathrm{~mm}$, four holes of $25 \mathrm{~mm}$ diameter, eight openings of $60 \mathrm{~mm}$ $\mathrm{x} 10 \mathrm{~mm}$ and capacity for $6 \mathrm{~kg}$ of grapes. The boxes were immediately placed and kept in cold chamber with constant temperature of $3{ }^{\circ} \mathrm{C}$ and relative humidity of the air between 90 and $95 \%$, with useful dimensions of $3.5 \mathrm{~m}$ length $\times 1.2 \mathrm{~m}$ width $\times 2.5 \mathrm{~m}$ height. The bunch length was quantified using a $150 \mathrm{~mm}$ stainless steel digital universal caliper (Model: MTX) in the same day of the harvest. The bunch weight was evaluated using a precision electronic scale $1 \mathrm{~kg}$ x $0.2 \mathrm{~g}$ (Brand: BALNET). The commercial production was quantified at the end of the research.

The physical evaluations were conducted during the harvest in 2015 and 2016. Chemical characteristics analyses (total soluble solids content, titratable acidity and hydrogenic potential) of the berries were determined with the evolution of the grape maturation. Four bunches were separated from each plot, using four plants per treatment and five berries of each bunch have been evaluated, destined to the evaluations of grape quality for soluble solids content and titratable acidity. The grapes were stored in thermal boxes and transported under refrigeration to the laboratory, where they were prepared and evaluated. All the analyses were conducted in triplicate. The $\mathrm{pH}$ was determined by potentiometry (AOAC, 2012) with the aid of a digital pHmetro Tekna model T-1000 by direct immersion of the electrode in the extract of crushed and homogenized fresh fruits. The total soluble solids content ( $\left.{ }^{\circ} \mathrm{Brix}\right)$ were determined by placing drops of the crushed fresh fruit extract, homogenized and filtered over the prism of a Reichert r2MINI digital refractometer.

The results obtained during 2015 and 2016 of the evaluated characteristics were submitted to the analysis of variance, using the SISVAR software (FERREIRA, 2014). The averages were compared by the Scott-Knott test (1974) at $5 \%$ probability.

\section{Results and Discussion}

Isabel precoce cultivar was superior for bunch length (Figure 6A), bunch weight (Figure 6B), and grape production (Figure $6 \mathrm{C}$ ) in the different percentages of water replacement necessary for this soil. These results can be related to the requirement of the cultivar to water replacement. It was also possible to observe that the cultivars increase the bunch length, bunch weight and grape production with the increased of water replacement in the soil. In a similar study Hardie and Considine (1976) observed the higher bunches weight in the grapevine supplied with $100 \%$ of the evapotranspiration rate. In general, the variation in the production by plant, berry size, among others in grape depends on the cultivar and water handling (GRANGEIRO et al., 2002). The plant adaptability in stress conditions is influenced by the duration and magnitude of the stress, in addition to genetic variability. In low water availability conditions in the soil, several metabolic processes in plants can be influenced, such as stomatic closure, decline in the growth rate, solutes and antioxidants accumulation and the manifestation of specific stress genes (MIGUEL et at., 2009). 

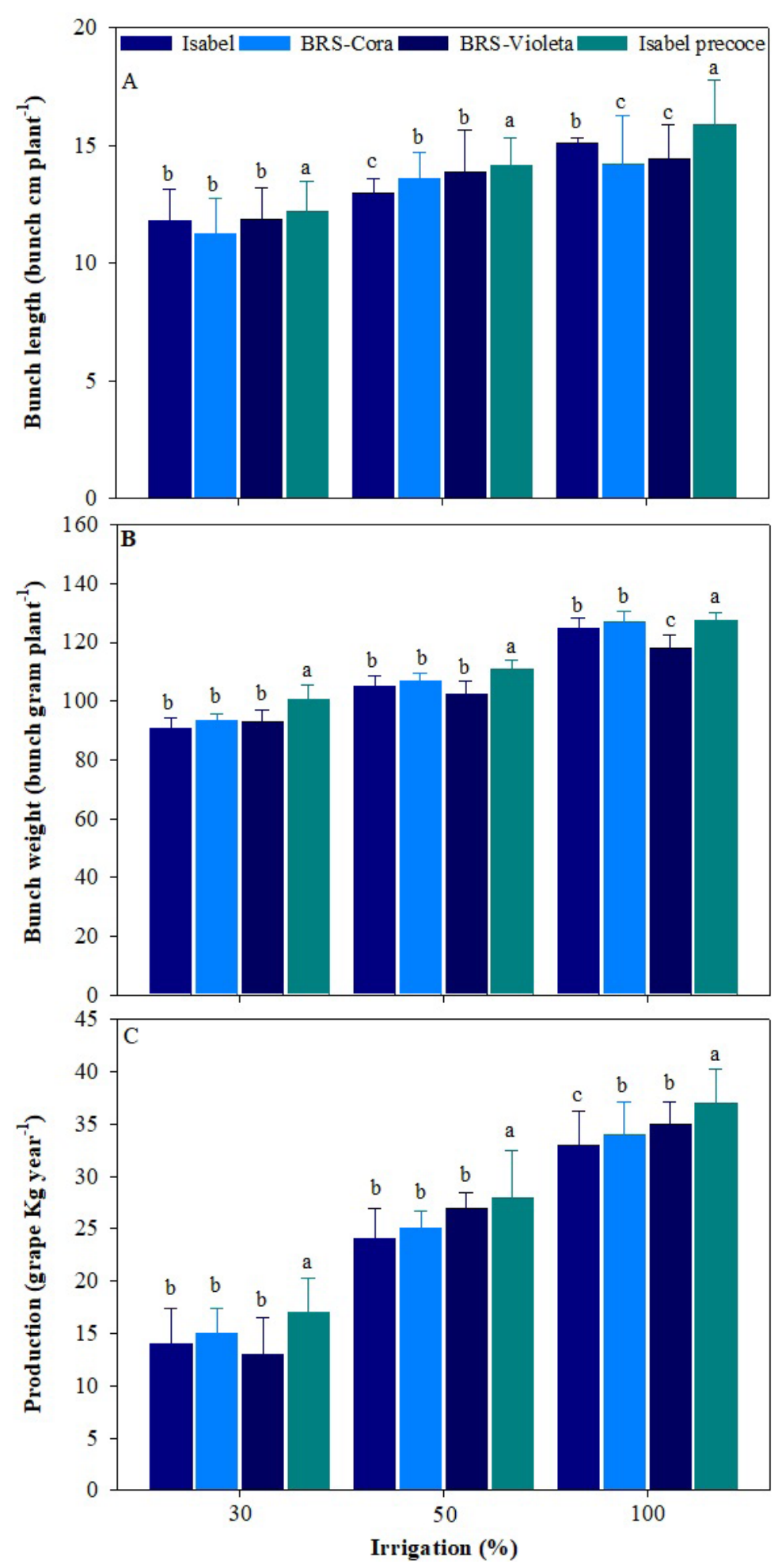

Figure 6. Bunch length (A), bunch weight (B) and grape production (C) depending on cultivars and percentages of water replacement for this type of soil in harvests from 2015 to 2016 (average of two years).

For $\mathrm{pH}$ (Figure 7A) determined directly in the fruit must submitted to the application of $100 \%$ water replacement in this type of soil provided $52 \%$ increase in the BRS-Cora cultivar that was higher compared to the lower water replacement. For the total acidity content (Figure 7B) BRS-Violeta cultivar had higher reduction of this parameter with the increase of water replacement in this type of soil. For the soluble solids content in ${ }^{\circ}$ Brix (Figure $7 \mathrm{C}$ ) Cora cultivar was superior $(84 \%)$ in the application of $100 \%$ water replacement in this type of soil compared to lower water replacement. According to the Standard Instruction number 14 (BRASIL, 2018) which establishes minimum required of $14{ }^{\circ} \mathrm{Brix}, \mathrm{pH} 2.99$ and total acidity 55 . In other studies, soluble solids contents from 14 to $18.9^{\circ}$ Brix (NAGATO et al., 2003); 14.21 to $17.3{ }^{\circ}$ Brix (SANTANA et al., 2008); 15.5 to $18.5^{\circ}$ Brix (ROMBALDI et al., 2004) were determined. For titratable acidity the maximum content of 0.90 grams of tartaric acid 
$/ \mathrm{g} 100 \mathrm{~mL}^{-1}$ of juice, it can also be related to the type of elaborated cultivar, because Concord and Isabel cultivars present relatively low must acidity around 3.44 (RIZZON; LIKON, 2006). It was possible to observe an increase in $\mathrm{pH}$, soluble solids content and reduction in total acidity content with the increase of water replacement in this type of soil. Grangeiro et al. (2002), working with the Seedless Superior cultivar in São Francisco River region, obtained soluble solids values, on average, of $17.3^{\circ} \mathrm{Brix}$, on the harvest period. These results were higher than those obtained by Santos et al. (2014) that obtained 15.5 ${ }^{\circ}$ Brix values for Seedless Superior cultivar, overcoming the minimum requirements mainly demanded by the external market. These results disagree with Marinho et al. (2010) that no variation in acidity content was observed when there was variation of the water level in grapevine irrigation. When there is water deficiency during the initial grapevine growth period and in the maturation of the berries, there will be a reduction in the fruit size and delay in its ripening, affecting its coloring and favoring its burning by solar radiation (ÁVILA NETO et al., 2000).
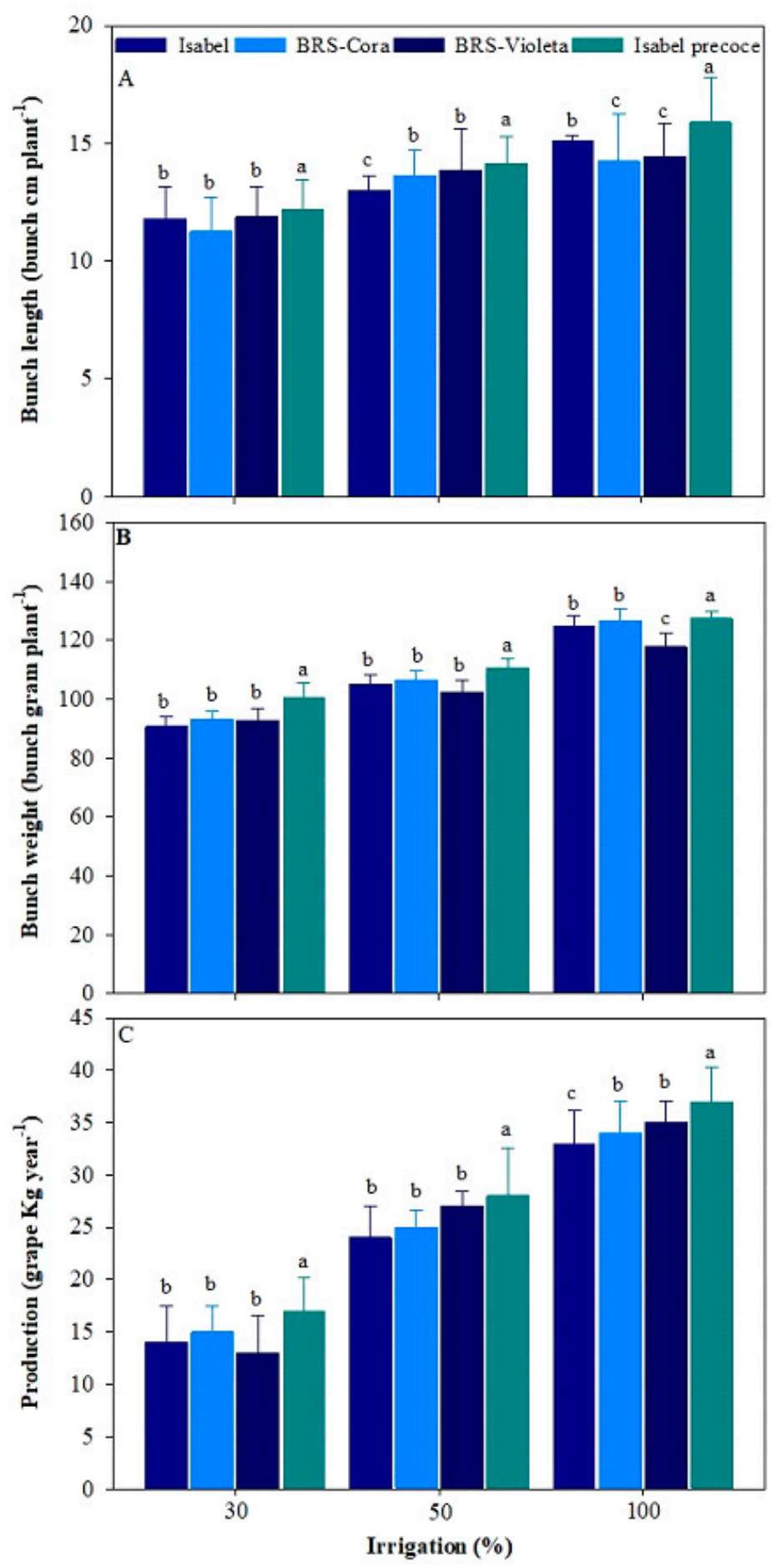

Figure 7. The $\mathrm{pH}(\mathrm{A})$, acidity (B) and soluble solids content (C) depending on cultivars and percentages of water replacement for this type of soil in harvests from 2015 to 2016 (average of two years). 


\section{Conclusions}

It is concluded with the research that Isabel, Isabel Precoce, BRS-Cora and BRS-Violeta increased by $75 \%$ bunch length $\left(\mathrm{cm}\right.$ plant $^{-1}$ year $\left.{ }^{-1}\right), 71 \%$ bunch weight ( gram plant $^{-1}$ year $\left.{ }^{-1}\right), 39 \%$ grape bunch production $\left(\mathrm{kg} \mathrm{year}^{-1}\right), 52$ $\% \mathrm{pH}, 84 \%$ soluble solids content and $60 \%$ reduction of total acidity content with $100 \%$ water replacement in the soil. Isabel precoce cultivar in water deficit conditions obtained the best productive results.

\section{Acknowledgments}

The authors would like to thank the National Council for Scientific and Technological Development (CNPq/Brazil) for the support.

\section{References}

ABE, L.T.; MOTA, R.V.; LAJOLO, F.M.; GENOVESE, M.I. Compostos fenólicos e capacidade antioxidante de cultivares de uvas Vitis labrusca L. e Vitis vinifera L. Ciência e Tecnologia de Alimentos, Campinas, v.27, n.2, p.394-400, 2007.

AOAC - Association of Official Analytical Chemistry. Official methods of analysis of the Association of Official Analytical Chemistry. Gaithersburg, 2012. 3000p.

ALLEN, R.G.; PEREIRA, L.S.; RAES, D.; SMITH, M. Crop e vapotranspiration: guidelines for computing crop water requirements. Rome: FAO, 1998. 300 p. (Irrigation and Drainage Paper, 56).

AMORIM, D.A.; FAVERO, A.C.; REGINA, M.A. Produção extemporânea da videira, cv. Syrah, nas condições do sul de Minas Gerais. Revista Brasileira de Fruticultura, Jaboticabal, v.27, n. 2, p. 327-331, 2005.

APARECIDO, L.E.O.; SOUZA, P.S.; FILHO, G.L.M.; PENHA, E.T.S. Desenvolvimento inicial de cultivares de videira em Muzambinho-MG. Revista Agrogeoambiental, Pouso Alegre, v.6, n.1, p.101-105, 2014.

ÁVILA NETO, J.; AZEVEDO, P. V. de; SILVA, B.B. da; SOARES, J.M.; TEIXEIRA, A.H. C. Exigência hídrica da videira na Região do Sub médio São Francisco. Pesquisa Agropecuária Brasileira, Brasília, DF, v.35, n. 8, p.1559$1566,2000$.
BRASIL, Ministério da Agricultura, Pecuária e Abastecimento. Instrução Normativa aplica-se ao vinho e derivados da uva e do vinho comercializados em todo o território nacional, produzidos no Brasil e importados. Instrução Normativa $n^{\circ} 14$, de 8 de fevereiro de 2018. Brasília, 2018.

CAMARGO, U.A.; TONIETTO, J.; HOFFMANN, A. Progressos na viticultura brasileira. Revista Brasileira de Fruticultura, Jaboticabal, 33, n.1, p. 144-149, 2011.

CAMARGO, U.; NACHTIGAL, J.; MAIA, J.; OLIVEIRA, P.; PROTAS, J. BRS Morena: nova cultivar de uva preta de mesa sem sementes. Bento Gonçalves: Embrapa Uva e Vinho, 2003. 4p.

FERREIRA D.F. Sisvar: a Guide for its Bootstrap procedures in multiple comparisons. Ciência e Agrotecnologia, Lavras, v.38, n.2, p.109-112, 2014.

FIETZ, C.R.; FOLEGATTI, M.V.; VIEIRA, S.R.; FRIZZONE, J.A. Efeito da variabilidade do armazenamento de água no solo na qualidade da irrigação por aspersão. Revista Brasileira de Engenharia Agrícola e Ambiental, Campina Grande, v.3, n.2, p.150-153, 1999.

GASPAR, N.A.; APARECIDO, L.E.O.; ROLIM, G.S.; SOUZA,P.S.; BOTELHOS,T.G. Software for the management of weather stations and for agrometeorological calculations. Australian Journal of Crop Science, Lismore, v. 9, n. 6, p.545-551, 2015.

GRANGEIRO, L.C.; LEAO, P. C.D.; SOARES, J.M. Caracterização fenológica e produtiva da variedade de uva Superior Seedless cultivada no Vale do São Francisco. Revista Brasileira Fruticultura, Jaboticabal, v.4, n.2, p.552-554, 2002.

HARDIE, W.J.; CONSIDINE, J. A. Response of grapes to water deficit stress in particular stages of development. American Journal of Enology and Viticulture, Redley, v.27, n.2, p.55-61, 1976.

HERNANDES, J.L.; Pedro Júnior, M.J. Niagara Rosada: sistema de condução em Y e em cultivo protegido. Informe Agropecuário, Belo Horizonte, v.36, p.7-12, 2015.

KELLER, J.; KARMELI, D. Trickle irrigation design. Glendora: RainBird Sprinkler Manufacturing, 1975. $133 p$. 
LUCIANO, R.V.; ALBUQUERQUE, J.A.; RUFATO, L.M.; DAVID, J.; WARMLING, M.T. Condições meteorológicas e tipo de solo na composição da uva 'Cabernet Sauvignon'. Pesquisa Agropecuária Brasileira, Brasília, DF, v.48, n.1, p.97-104, 2013.

MAIA, J. D. G.; RITSCHEL, P.; Lazzarotto, J.J. Viticultura de Mesa no Brasil: produção para o Mercado Nacional e Internacional. Territoires du vin, v.9, p. 1-10, 2020. Disponível em: http://preo.u-bourgogne.fr/ territoiresduvin/index.php?id=1546. Acesso em: 29 jan. 2020 .

MARINHO, L.B.; RODRIGUES, J.J.V.; SOARES, J.M.; COELHO, M.A.L. Produção e qualidade da videira 'Superior Seedless' sob restrição hídrica na fase de maturação. Pesquisa Agropecuária Brasileira, Brasília, DF, v.44, n.12, p.1682-1691, 2010.

MARQUES, D.J.; SIQUEIRA, J.A.C.; BIANCHINI, H.C.; ALVES, V.M. Production of passion fruit in a semihydroponic system under protected cultivation. Revista Brasileira de Fruticultura, Jaboticabal, v.41, n.6, p.1-12, 2019.

MIGUEL, A.C.A.; DIAS, J.R.PS.; ALBERTINI, S.; SPOTO, M.H.F. Pós-colheita de uva 'Itália' revestida com filmes à base de alginato de sódio e armazenada sob refrigeração. Ciência Tecnologia Alimentos, Campinas, n.29, v.2, p.277-282, 2009.

NACHTIGAL, J.C.; BOTTON, M.; SANTOS, H.P.; GARRIDO, L.R.; HILLEBRAND, F.; ONSI, G.; BELLÉ, $V$. Recomendações para produção de uvas de mesa em cultivo protegido na região da Serra Gaúcha. Bento Gonçalves: Embrapa Uva e Vinho, 2010. 28p.

NAGATO, L.A.F.; RODAS, M.A.B.; DELLA TORRE, J.C.M.; CANO, C.B.; YOTSUYANAGY, K. Parâmetros físicos e químicos e aceitabilidade sensorial de sucos de frutas integrais, maracujá e uva, de diferentes marcas brasileiras. Brazilian Journal of Food Technology, Campinas, v.6, n.1, p.127-136, 2003.
RIZZON, L.A.; LINK, M. Composição do suco de uva caseiro de diferentes cultivares. Ciência Rural, Santa Maria, v. 36, n. 2, p. 689-692, 2006.

ROMBALDI, C.V.; BERGAMASQUI, M.; LUCCHETTA, L.; MARCIO ZANUZO, M.; SILVA, J.A. Produtividade e qualidades de uva, cv. Isabel, em dois sistemas de produção. Revista Brasileira de Fruticultura, Jaboticabal, v.26, n.1, p.89-91, 2004.

SANTANA, M.T.A.; SIQUEIRA, H.H.D.E.; REIS, K.C.; LIMA, L.C.O.; SILVA, R.J.L. Caracterização de diferentes marcas de sucos de uva comercializados em duas regiões do Brasil. Ciência e Agrotecnologia, Lavras, v. 32, n.3, p.882-886, 2008.

SANTOS, A.E.O. dos; SILVA, E. de O.; OSTER, A.H.; DE LIMA, M.A.C.; MISTURA, C.; BATISTA, P.F. Evolução da maturação fisiológica de uvas apirenas cultivadas no Vale do Submédio do São Francisco. Revista Brasileira de Ciências Agrárias, Pernambuco, v.9, n.1, p.25-30, 2014.

SANTOS, A.O.; KAYE, O. Composição quali-quantitativa da produção de 'Syrah' cultivada sob estresse hídrico transiente. Revista Brasileira de Engenharia Agrícola e Ambiental, Campina Grande, v.13, p.272-281, 2009.

SCOTT, A.J.; KNOTT, M. A cluster analysis method for grouping means in the analysis of variance. Biometrics, Washington, v.30, n.3, p.507-512, 1974.

SERMAN, V.F.; LIOTA, M.; PARERA, C. Effects of irrigation deficit on table grape cv. Superior seedless production. Acta Horticulturae, Amsterdam, n.646, p.183-186, 2004.

THORNTHWAITE, C.W. An approach towards a rational classification of climate. Geographical Review, New York v.38, n.1, p.55-94, 1948. 